\title{
Characterization and Epidemiological Significance of Potato Plants Grown from Seed Tubers Affected by Zebra Chip Disease
}

\author{
D. C. Henne and F. Workneh, Texas AgriLife Research, Bushland, TX 79012; A. Wen, Department of Plant Pathol- \\ ogy, North Dakota State University, Fargo 58108; J. A. Price, Texas AgriLife Research; J. S. Pasche and \\ N. C. Gudmestad, Department of Plant Pathology, North Dakota State University; and C. M. Rush, Texas AgriLife \\ Research
}

\begin{abstract}
Henne, D. C., Workneh, F., Wen, A., Price, J. A., Pasche, J. S., Gudmestad, N. C., and Rush, C. M. 2010. Characterization and epidemiological significance of potato plants grown from seed tubers affected by Zebra Chip disease. Plant Dis. 94:659-665.

An emerging disease of potato in the United States, known as "Zebra Chip" or "Zebra Complex" (ZC), is increasing in scope and threatens to spread further. Here, we report on studies performed to understand the role of tuberborne $\mathrm{ZC}$ in the epidemiology of this disease. Depending on variety, up to $44 \%$ of ZC-affected seed tubers (ZCST) were viable, producing hair sprouts and weak plants. Chip discoloration in progeny tubers of ZCST was more severe than those from ZCasymptomatic seed tubers but varied depending on whether progeny tubers or foliage were positive or negative for 'Candidatus Liberibacter solanacearum'. A low percentage of greenhousegrown plants produced by ZCST tested positive for ' $\mathrm{Ca}$. Liberibacter'. No adult potato psyllids became infective after feeding upon these plants but they did acquire ' $\mathrm{Ca}$. Liberibacter' from field-grown plants produced by ZCST. Plants with new ZC infections near plants produced by ZCST were not significantly different from healthy plants, whereas plants affected with ZC from infectious potato psyllids had significantly more ZC infections near either plants produced by ZCST or healthy plants. We conclude that, in areas where ZC is currently established, plants produced by ZCST do not significantly contribute to ZC incidence and spread within potato fields.
\end{abstract}

Tuberborne diseases of potato, such as Potato virus $Y$ and Potato leafroll virus, present significant problems for potato seed growers and producers alike. An emerging disease of potato, called "Zebra Chip" or "Zebra Complex" (ZC), has recently appeared in the United States and elsewhere and is causing significant losses to individual growers and processors. First identified in northeastern Mexico in 1994 and south Texas in 2000, ZC has been reported from at least eight states within the United States, and was recently reported from New Zealand (7).

Plants affected by ZC exhibit a broad range of symptoms that are similar to potato purple top (9-11): stunting, chlorosis, leaf scorching, swollen internodes near apical portions, axillary bud and aerial tuber proliferation, necrosis of vascular system, and early death. The name "Zebra Chip" refers

Corresponding author: Don Henne

E-mail: DCHenne@ag.tamu.edu

Accepted for publication 3 February 2010.

doi:10.1094/PDIS-94-6-0659

(C) 2010 The American Phytopathological Society to the characteristic brown discoloration of the vascular ring and medullary ray tissues within the tubers that is enhanced when tubers are sliced and fried into chips.

Although the pathogen causing $\mathrm{ZC}$ has defied efforts at identification, recent research strongly suggests that the fastidious bacterium 'Candidatus Liberibacter solanacearum' is involved in causing ZC (68 ). It has been demonstrated that ' $\mathrm{Ca}$. L. solanacearum' is vectored by the potato psyllid, Bactericera cockerelli Sulc. (Heteroptera: Psyllidae), $(10,11)$ and this insect is widespread within the western and central United States, migrating northward annually during the spring and summer from breeding areas in the southwestern United States and northern Mexico. However, evidence is accumulating that not all $B$. cockerelli harbor ' $C a$. L. solanacearum' $(15,16)$.

One factor that must be considered in the spread of $\mathrm{ZC}$ is the potential role of tuberborne (=seedborne) inoculum. Potato crops are maintained by vegetative propagation of "seed" tubers, a process by which tuberborne diseases present in the propagative material can be systematically transmitted to sprouts and progeny tubers $(2,17)$. Previously, ZC was not reported from potato seed production areas within the United States. However, Wen et al. (20) confirmed the presence of ' $\mathrm{Ca}$. L. solanacearum' in certified seed potato tubers produced from Wyoming in 2007 and Nebraska in 2008. In 2008, plants exhibiting aerial symptoms of tuberborne ZC (Fig. $1 \mathrm{~A})$ were identified in several commercial potato fields at two widely separated locations in the Texas Panhandle. In contrast to diseased plants that were infected by bacterioliferous adult B. cockerelli (Fig. 1B), plants with tuberborne disease are stunted, often less than $15 \mathrm{~cm}$ in height, and the foliage displays a marked 'witches broom' appearance; however, a small percentage are apparently nearly asymptomatic (N. C. Gudmestad, personal observations). In addition, symptoms of $B$. cockerelliinduced ZC symptoms do not normally appear until after flowering, whereas diseased tuberborne plants appear soon after emergence. This source of the infection in early-infected plants is suspected to be the seed tubers themselves and not the result of feeding by ' $\mathrm{Ca}$. L. solanacearum'infectious $B$. cockerelli.

It is clear that $\mathrm{ZC}$ is spreading to new potato production areas, especially in the western United States, and has potential to develop wherever B. cockerelli is found. Because $B$. cockerelli has been implicated as the vector associated with $\mathrm{ZC}$, there is concern that noninfectious, abacterioliferous $B$. cockerelli could acquire the pathogen from ZC-affected tuberborne plants and transmit it to nearby healthy plants, especially in areas where ZC has not been reported previously (20). It has been suggested that ZC-affected tubers rarely sprout $(10,15)$, despite a paucity of data to substantiate that claim. Thus, there is a need to characterize the growth and morphology of plants produced by ZCsymptomatic seed tubers and determine the viability of affected tubers. The objectives of this study were to (i) determine the germination success of ZC-affected tubers and characterize the morphology and growth patterns of plants growing from ZC-affected tubers, (ii) characterize chip discoloration in progeny tubers of plants produced by ZC-symptomatic and ZCasymptomatic seed tubers, (iii) determine 
whether adult $B$. cockerelli can acquire ' $C a$. L. solanacearum' from plants produced by ZC-symptomatic seed tubers, and (iv) investigate the impact of tuberborne $\mathrm{ZC}$ plants on subsequent disease incidence in commercial fields.

\section{MATERIALS AND METHODS}

Tuber germination, plant growth and morphology, and ' $\mathrm{Ca}$. L. solanacearum' titer levels. Two tuber germination studies were performed in greenhouses located in Fargo, ND and Bushland, TX to assess germination of ZC-affected tubers and subsequent plant viability and growth characteristics. North Dakota greenhouse studies were conducted in 2006 and 2007, prior to the discovery of ' $\mathrm{Ca}$. L. solanacearum' as the putative $\mathrm{ZC}$ agent, and evaluated seed tubers $(n=99$ and 97 , respec- tively) obtained from commercial potato farms located in the Texas Panhandle in September and October of 2005 and 2006 , respectively. The seed tubers represented a mixture of two potato cultivars in both years of the study, FL1867 and Atlantic. North Dakota greenhouse studies examined type of sprout (hairsprout versus normal versus witches broom morphology), percent emergence, and percent survival 4

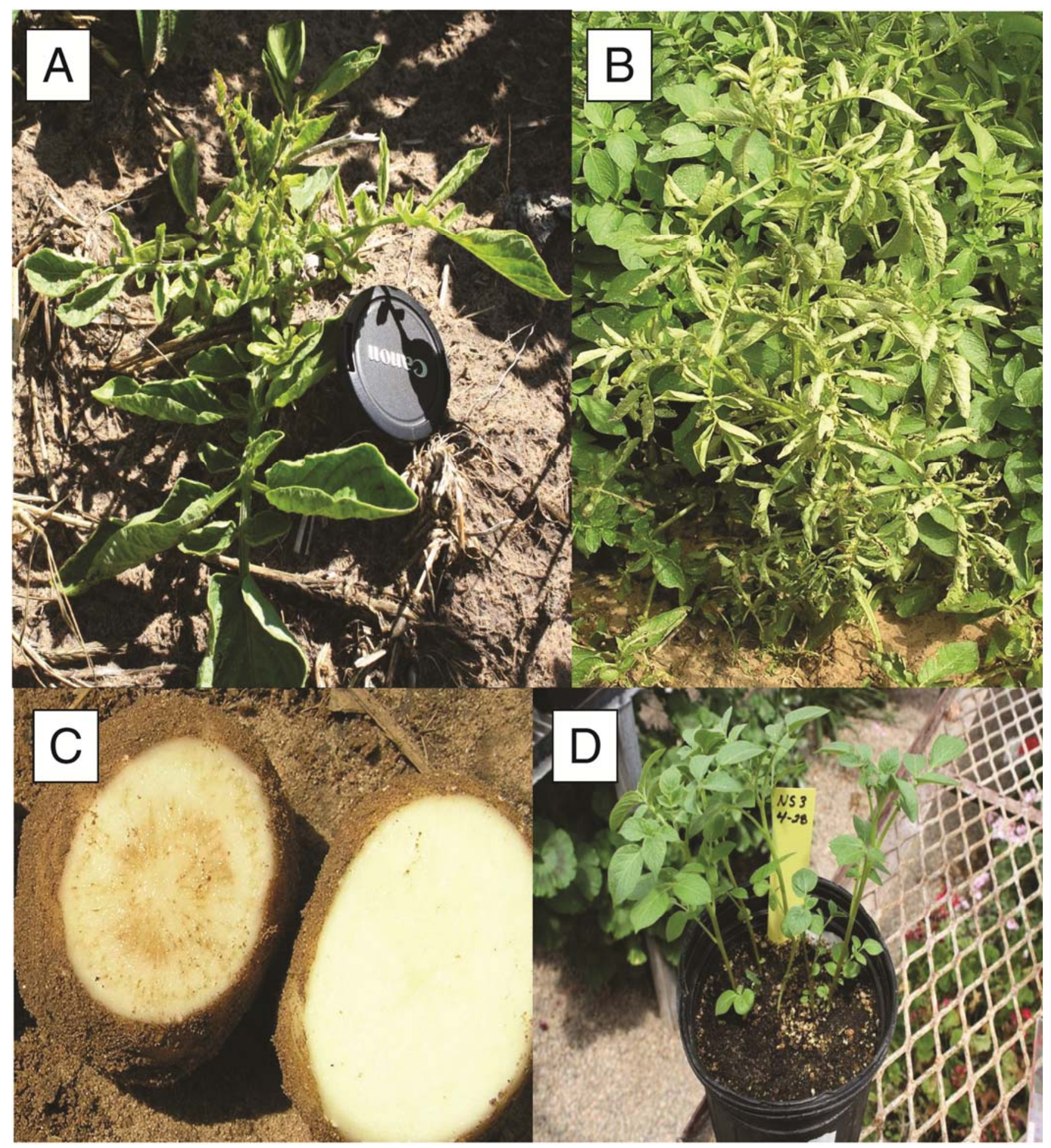

Fig. 1. A, Tuberborne Zebra Chip (ZC) plant growing in a potato field near Olton, TX in June 2009; B, typical psyllid-borne ZC-affected potato plant; C, excavated Russet Norkotah tubers that have been cut open to display internal ZC symtoms in raw tuber (left) compared with a disease-free raw tuber (right); $\mathbf{D}$, Tuberborne ZC hair sprouts growing in the greenhouse (contrast with field-grown plant in $\mathbf{A}$ ). 
weeks after emergence. Non-hairsprout plants were further categorized into haywire type or normal morphology. Haywire is a morphological characteristic of potato plants growing from tubers affected by a number of phytoplasmas (18).

Texas greenhouse studies were conducted in 2009 on cv. Russet Norkotah tubers $(n=484)$ collected 23 September 2008 from mature Russet Norkotah plants exhibiting symptoms of $\mathrm{ZC}$ in a field in Dalhart, TX. Upon excavation, a 1- to 2$\mathrm{cm}$ portion was removed from the stolon end of each tuber to obtain visual confirmation of ZC (Fig. 1C). After collection, tubers were first stored in a large cooler for 3 months at $5^{\circ} \mathrm{C}$ to break dormancy, and then stored at $20^{\circ} \mathrm{C}$ for approximately 3 weeks, after which only those displaying evidence of sprouting were used in laboratory trials. Two trials were performed. The first trial was initiated on 26 January 2009 and the second trial was initiated on 28 April 2009. ZC-affected tubers, as well as disease-free (control) tubers, were planted in individual 3.83-liter plastic pots and maintained in the greenhouse at a natural photoperiod and an average temperature of $23^{\circ} \mathrm{C}$ (first trial) and $26^{\circ} \mathrm{C}$ (second trial). A few tubers were too large for the pots and were cut in half, allowed to suberize, and then planted separately. Numbers of shoots and shoot lengths were measured at 16, 23, $32,38,44$, and 51 days after planting (DAP) in trial 1 and at 10, 17, 23, 31, and 38 DAP in trial 2. Basal stem diameters of sprouts from diseased and healthy tubers were measured with a digital caliper (Performance Tool no. W80152, Tukwila, WA) at the termination of each trial.

Texas trial leaf-tissue samples were tested for the presence and titer levels of ' $C a$. L. solanacearum' using real-time polymerase chain reaction (PCR) methods described by Wen et al. (20), with slight modifications. On 2 March 2009 (35 DAP, trial 1) and 27 May 2009 (27 DAP, trial 2), 0.8 - to $0.10-\mathrm{g}$ samples of midvein leaf tissue were excised from a randomly selected leaf located approximately halfway up each plant. Relative quantification (RQ) was conducted using a 7000 Sequence Detection System from Applied Biosystems, Inc. (Foster City, CA). ' $\mathrm{Ca}$. L. solanacearum'-specific primers were synthesized by Integrated DNA Technologies (Coralville, IA) and the probe was synthesized by Applied Biosystems. An endogenous control was included in the reaction by using primers and probe sequences specific for the 18s ribosomal RNA (Applied Biosystems). Each sample was compared to a calibrator sample of low target value to estimate target concentration within each sample. Results are shown as RQ $\log _{10}$ times greater than or less than the calibrator for each sample. Stems, leaves, seed tubers, and progeny tubers produced by plants produced by ZC-symptomatic seed tubers from trial 2 were also tested for presence of 'Ca. L. solanacearum'. A third seed-germination study was performed at Fargo, ND in 2009. Thirty-six seed tubers of cv. Ranger Russet exhibiting or not exhibiting typical symptoms of ZC were collected from a Nebraska potato storage in February 2009 from the 2008 potato crop. Tubers were cut, horizontally or both horizontally and vertically, into either two or four sections based on the size of the potato tuber, and planted on 21 April 2009. Plants were grown under 16-h days at $25 \pm$ $2^{\circ} \mathrm{C}$ with a standard pesticide regime. Emergence and survival of plants produced from both ZC- and non-ZC-symptomatic seed tubers were recorded every 7 days beginning 7 DAP and continuing until 56 DAP. The presence of ' $\mathrm{Ca}$. L. solanacearum' in seed, foliage, and progeny tubers was detected using the conventional PCR (cPCR) assay by (5).

Chip characterization. Progeny tubers grown from plants produced in 2009 in the third seed-germination study by non-ZCsymptomatic seed tubers and seed tubers with typical symptoms of ZC were harvested 120 and 146 DAP, respectively. All progeny tubers were stored at $13^{\circ} \mathrm{C}$ for 4 and 30 days for ZC and non-ZC progeny tubers, respectively, prior to sectioning and chip evaluation. Tubers produced from plants grown from ZC-affected seed tubers were harvested earlier (120 DAP) than from plants produced from healthy seed tubers (146 DAP) because the plants produced from ZC-affected seed tubers died prematurely compared with the healthy potato plants. Tubers were sliced using a hand-held mandolin slicer (Oxo Goodgrips, New York) to $2.23 \pm 0.10 \mathrm{~mm}$, rinsed with tap water to remove free starches, and dried using paper towels. Approximately $60 \mathrm{~g}$ of potato tuber slices of progeny tubers displaying no sign of discoloration and $25 \mathrm{~g}$ of progeny tubers with symptoms typical of ZC were used for chip frying. Tubers produced from healthy plants were larger than those from ZC-affected seed tubers, resulting in differential weights of tuber slices obtained from non-ZC tubers (60 g) compared with $\mathrm{ZC}$-affected tubers $(25 \mathrm{~g}$ ). Tuber slices were processed into chips in 9 liters of foodgrade vegetable oil heated to $190^{\circ} \mathrm{C}$ using a deep fryer for $3 \mathrm{~min}$ for slices of non-ZC progeny tubers and for $2 \mathrm{~min}$ for tuber slices of ZC-progeny tubers, respectively. Because tuber slices from ZC-progeny tubers were so small $(25 \mathrm{~g})$, they could not be fried for the full 3 min; otherwise, the sugars would completely caramelize, thereby inhibiting the ability to successfully score the level of chip discoloration. Chip discoloration was scored using a 0 -to- 3 scale where $0=$ no discoloration, $1=$ mild vascular tissue discoloration, $2=$ severe vascular tissue discoloration, and $3=$ medullary ray discoloration typical of ZC.

Seed tubers, foliage (leaf and petiole), and progeny tubers were tested for the presence of ' $\mathrm{Ca}$. L. solanacearum' using a previously established cPCR assay (5). Foliar sampling of plants produced from non-ZC-symptomatic seed tubers was conducted 35 DAP, while foliar sampling of plants produced from seed tubers with symptoms typical of ZC was conducted on an ongoing basis due to the erratic nature of emergence and survival of these plants.

Evaluation of $\boldsymbol{B}$. cockerelli acquisition of ' $\mathrm{Ca}$. L. solanacearum' from plants produced by ZC-symptomatic seed tubers. Greenhouse experiments were conducted in Texas to determine whether $B$. cockerelli free of ' $C a$. L. solanacearum' could acquire it by feeding on plants produced by ZC-symptomatic seed tubers. After termination of Texas greenhouse trial 1 , five plants produced by ZCsymptomatic seed tubers that tested positive for ' $\mathrm{Ca}$. L. solanacearum' were used as host plants. On each positive host plant, $>100$ ' $C a$. L. solanacearum'-free adult $B$. cockerelli from a ' $\mathrm{Ca}$. L. solanacearum'free colony were confined and allowed to feed for 7 days. A subsample of adult $B$. cockerelli were then aspirated from each cage and tested for ' $\mathrm{Ca}$. L. solanacearum' using real-time PCR methods as in the previous section to verify acquisition. Several hundred ' $\mathrm{Ca}$. L. solanacearum'-free $B$. cockerelli adults were also confined on two plants produced by ZC-symptomatic seed tubers that were collected from a commercial potato field near Olton, TX on 25 June. After the 7-day acquisition period, adult $B$. cockerelli were tested for ' $\mathrm{Ca}$. L. solanacearum' using standard PCR methods.

Seedborne disease surveys. On 11 June 2008, a commercial potato field (cv. Russet Norkotah, planted 13 to 14 March 2008) located near Olton, TX was surveyed for seedborne $\mathrm{ZC}$ and psyllid-borne ZC. Forty plants, each with the following characteristics, were located and marked with wire stake flags of different colors: plants produced by ZC-symptomatic seed tubers (Fig. 1A), psyllid-borne ZC plants (Fig. 1B), and healthy plants. Psyllid-borne ZC plants were those presumably infected by $B$. cockerelli and not resulting from ZCaffected seed tubers. All marked plants were isolated from other diseased plants by at least $10 \mathrm{~m}$. On 1 July 2008, plants exhibiting ZC-like foliar symptoms within a $2-\mathrm{m}$ radius of the originally marked plants were counted. A 2-m radius was chosen because this is within the short-range movement of adult B. cockerelli (D. C. Henne, personal observations). Tubers from plants with ZC-like foliar symptoms were excavated to verify whether tuber symptoms consistent with ZC were present (10,11; Fig. 1C).

A second disease survey was performed on 25 June 2008 in a commercial Russet Norkotah potato field (planted 5 April 2008) located near Dalhart, TX. Only 25 plants produced by ZC-symptomatic seed 
tubers and 18 asymptomatic plants that were at least $10 \mathrm{~m}$ from the nearest $\mathrm{ZC}$ symptomatic plant could be located in this field. No psyllid-borne ZC plants that were isolated by at least $10 \mathrm{~m}$ from other diseased plants could be found at this location. Therefore, the second survey compared the incidence of ZC in plants surrounding the originally marked seedborne versus asymptomatic (control) plants. On 15 July 2008, marked plants at the Dalhart location were revisited and assessed for disease incidence within $2 \mathrm{~m}$ of marked plants, as described above.

Statistical analyses. Statistical analyses were performed using SAS 9.2 (14). Plant height data were log transformed to stabilize variances. Differences in mean plant

Table 1. Percent emergence of healthy and Zebra Chip (ZC)-affected potato seed tubers collected in the Texas panhandle (October 2005) and planted in the greenhouse in North Dakota (January 2006) ${ }^{\mathrm{w}}$

\begin{tabular}{|c|c|c|c|}
\hline Seed $^{x}$ & $\begin{array}{c}\text { No. of } \\
\text { seed } \\
\text { pieces }\end{array}$ & $\begin{array}{c}\text { Any } \\
\text { plant }^{y}\end{array}$ & $\begin{array}{l}\text { Viable } \\
\text { plant }^{\mathrm{z}}\end{array}$ \\
\hline Healthy & 50 & $74.0 \mathrm{a}$ & $74.0 \mathrm{a}$ \\
\hline $\mathrm{ZC}$ & 147 & $42.9 \mathrm{~b}$ & $32.0 \mathrm{~b}$ \\
\hline
\end{tabular}

${ }^{\text {w }}$ Values within columns followed by a different letter are statistically different based on Fisher's protected least significant difference $(\alpha=0.05)$.

${ }^{\mathrm{x}}$ Healthy $=$ seed tuber displaying no sign of vascular discoloration and $\mathrm{ZC}=$ seed tubers displaying discoloration of vascular and medullary ray tissue typical of ZC.

${ }^{y}$ Emergence of any type, including hairsprouts.

${ }^{\mathrm{z}}$ Plants comparable in size to a healthy plant. Therefore, the difference between "Any plant" and "Viable plant" represents the frequency of hairsprout plants which were severely stunted and died shortly after emergence.

Table 2. Percent emergence of healthy and Zebra Chip (ZC)-affected potato seed tubers collected in the Texas panhandle (October 2006) and planted in the greenhouse in North Dakota (January 2007) $^{\mathrm{w}}$

\begin{tabular}{lccc}
\hline Seed $^{\mathrm{x}}$ & $\begin{array}{c}\text { No. of } \\
\text { seed } \\
\text { pieces }\end{array}$ & $\begin{array}{c}\text { Any } \\
\text { plant }^{\mathrm{y}}\end{array}$ & $\begin{array}{c}\text { Viable } \\
\text { plant }^{\mathbf{z}}\end{array}$ \\
\hline Healthy & 5 & $80.0 \mathrm{a}$ & $80.0 \mathrm{a}$ \\
Mild ZC & 48 & $43.8 \mathrm{~b}$ & $43.8 \mathrm{~b}$ \\
Severe ZC & 46 & $23.9 \mathrm{~b}$ & $6.5 \mathrm{c}$ \\
\hline
\end{tabular}

${ }^{\text {w}}$ Values within columns followed by a different letter are statistically different based on Fisher's protected least significant difference $(\alpha=0.05)$.

${ }^{\mathrm{x}}$ Healthy $=$ seed tuber displaying no sign of vascular discoloration, Mild ZC = seed tubers displaying mild vascular discoloration, and Severe $\mathrm{ZC}=$ seed tubers displaying discoloration of vascular and medullary ray tissue typical of ZC.

${ }^{y}$ Emergence of any type, including hairsprouts.

${ }^{\mathrm{z}}$ Plants comparable in size to a healthy plant. Therefore, the difference between "Any plant" and "Viable plant" represents the frequency of hairsprout plants which were severely stunted and died shortly after emergence. heights and stem diameters between $\mathrm{ZC}$ and healthy control plants were assessed by an independent $t$ test. Numbers of aboveground stems were compared using the Wilcoxon Signed-Ranked test, for which DAP and tuber integrity ( $\mathrm{ZC}$ versus healthy) were the explanatory variables. Data from plant emergence and chip discoloration studies were analyzed using a one-way analysis of variance using Proc GLM. Analyses were performed on percent emergence at each observation date, comparing plants produced from ZCsymptomatic and asymptomatic seed tubers, and means were differentiated using Fisher's protected least significant difference test $(\alpha=0.05)$. To evaluate the intensity of vascular discoloration among progeny tubers produced by ZC-symptomatic and asymptomatic seed tubers as well as ' $\mathrm{Ca}$. L. solanacearum'-positive and -negative seed tubers and foliage, $\chi^{2}$ tests of homogeneity were performed. For seedborne disease surveys at Olton and Dalhart, a $\chi^{2}$ test was performed on numbers of diseased plants in association with plants produced by ZC-symptomatic seed tubers, psyllid-borne ZC plants (Olton only), and healthy plants. The null hypothesis was that each plant category had equal incidence of $\mathrm{ZC}$-diseased plants within $2 \mathrm{~m}$ of the focal plant.

\section{RESULTS}

Tuber germination, plant growth and morphology, and ' $\mathrm{Ca}$. L. solanacearum' titer levels. In the North Dakota greenhouse studies, nearly $44 \%$ of Ranger Russet tubers sprouted (Tables 1 and 2) whereas, in the Texas greenhouse studies, $18 \%$ of ZC-affected Russet Norkotah tubers sprouted. In the North Dakota greenhouse studies, percent emergence of plants from severely affected tubers was significantly lower $(P<0.05)$ than both healthy tubers and tubers showing only mild ZC symptoms. The percent emergence of plants from ZC-affected seed tubers was significantly lower $(P<0.05)$ than the emergence obtained from healthyappearing seed tubers at all dates of evaluation (Table 3). Emergence was more rapid and survival was $>95 \%$ from healthy seed tubers at each date. In contrast, plants from seed tubers affected with ZC was much slower and only exceeded 40\% 42

Table 3. Mean percent emergence or survival under greenhouse conditions in 2009 of Zebra Chip (ZC)-affected and nonaffected tubers collected from storage in Nebraska

\begin{tabular}{lrrrrrrc}
\hline & \multicolumn{7}{c}{ Days after planting } \\
\cline { 2 - 8 } Seed tuber $^{\mathbf{z}}$ & $\mathbf{7}$ & $\mathbf{1 4}$ & $\mathbf{2 1}$ & $\mathbf{2 8}$ & $\mathbf{3 5}$ & $\mathbf{4 2}$ & $\mathbf{5 6}$ \\
\hline Seedborne ZC & 6.1 & 10.2 & 28.6 & 31.6 & 37.8 & 43.9 & 41.8 \\
No ZC & 95.9 & 95.9 & 95.9 & 95.9 & 95.9 & 95.9 & 99.0 \\
LSD $_{P=0.05}$ & 6.3 & 7.3 & 9.8 & 10.1 & 10.5 & 10.7 & 10.1 \\
\hline
\end{tabular}

${ }^{\mathrm{z}}$ In total, 98 seed pieces from 36 seed tubers for both ZC-affected and nonaffected tubers were planted in Plant Pathology Department greenhouse at North Dakota State University and observed for emergence or survival. Seedborne $\mathrm{ZC}=$ seed tubers displaying discoloration of vascular and medulary ray tissue discoloration typical of $\mathrm{ZC}$ and $\mathrm{No} \mathrm{ZC}=$ seed tubers displaying no sign of vascular discoloration. $\mathrm{LSD}=$ least significant difference.

DAP (Table 3). Germination of ZCaffected tubers initially was very low but after sprouting, survival of sprouts from tubers with severe ZC symptoms was significantly lower $(P<0.05)$ than sprouts from tubers with mild ZC symptoms. Sprouts from ZC-affected tubers initially would grow for a few weeks, after which time growth would slow dramatically or completely stop.

In general, stems of plants resulting from ZC-affected tubers were shorter than length of plants produced by $\mathrm{ZC}$ symptomatic seed tubers was initially equal to healthy controls up to 23 DAP, significantly longer than healthy controls at $32 \mathrm{DAP}(\mathrm{df}=24, t=-3.48, P=0.0019)$, and significantly shorter than healthy controls after approximately 40 DAP (44 DAP df $=55, t=2.35, P=0.0224)$. In 2 , mean tuberborne ZC plant stems were significantly shorter than healthy controls from $23 \mathrm{DAP}$ on $(23 \mathrm{DAP} \mathrm{df}=19, t=$ $P=0 . P=0.019 ; 31 \mathrm{DAP} \mathrm{df}=20, t=3.84$ $0.0319)$. ZC-affected tubers predominantly produced hairsprout-type plants that had stems significantly smaller in diameter and less robust than healthy control stems (trial $=58, t=11.96, P<0.0001)$. In trial $1, \mathrm{ZC}$ tubers produced significantly more sprouts than healthy controls from 23 DAP on (23 DAP $P<0.05 ; 32,38,44$, and 51 DAP $P<$ cant . In trial 2 , there were no signifisprouts produced by either plants produced by ZC-symptomatic seed tubers or healthy controls throughout the duration of the experiment.

PCR testing of various plant parts arising from either ZC-affected or non-ZCaffected seed tubers revealed generally
sporadic detection of ' $\mathrm{Ca}$. L. solanacearum' (Table 4). RQ $\log _{10}$ values from excised leaf midveins of plants from the Texas trial ranged between -0.6 and -1.7 . The only stem piece that tested positive for 0.4 . The solanacearum had an RQ $\log _{10}=$ tive had RQ $\log _{10}$ values of 0.9 and 1.1.

Chip characterization. Progeny tubers from ZC-symptomatic seed tubers had 
significantly $(P<0.0001)$ greater severity of chip discoloration than progeny tubers from ZC-asymptomatic seed tubers (Fig. 2A). However, there were no differences in levels of chip discoloration between progeny tubers produced from ' $\mathrm{Ca}$. L. solanacearum'-positive and -negative ZCasymptomatic seed tubers $(P=0.34$; Fig. 2B) or ' $\mathrm{Ca}$. L. solanacearum'-positive and -negative ZC-symptomatic seed tubers $(P$ $=0.09$; Fig. $2 \mathrm{C}$ ). There also were no differences in chip discoloration among progeny tubers produced from ZC-symptomatic seed tubers in which foliage tested positive or negative ( $P=0.18$, Fig. 2D) Additionally, there were no differences in chip discoloration in progeny tubers produced from seed tubers that were either positive or negative, regardless of whether or not the seed tubers were ZC symptomatic or asymptomatic ( $P=0.20$; Fig. $2 \mathrm{E})$.

Evaluation of $B$. cockerelli acquisition of ' $C a$. L. solanacearum' from plants produced by ZC-symptomatic seed tubers. Adult B. cockerelli did not test positive for ' $C a$. L. solanacearum' after confinement for at least 1 week with ' $\mathrm{Ca}$. L. solanacearum'-positive plants produced by ZC-symptomatic seed tubers grown in the greenhouse. However, ' $\mathrm{Ca}$. L. solanacearum'-free adult $B$. cockerelli that were confined with field-collected plants produced by ZC-symptomatic seed tubers for at least 1 week did test positive. Titer levels were much higher in foliage of fieldcollected plants produced by ZCsymptomatic seed tubers (average RQ $\log _{10}=1.45, n=4$ ) than plants produced by ZC-symptomatic seed tubers grown in the greenhouse from field-collected ZCaffected tubers (average RQ $\log _{10}=-1.1, n$ $=7$ ).

Disease surveys. At Olton, the incidence of new ZC infections appearing within $2 \mathrm{~m}$ of plants produced by ZCsymptomatic seed tubers was not significantly different from those around the healthy controls ( $\mathrm{df}=1, \chi^{2}=0.95, P=$ 0.30 ), indicating that the number of new infections detected around plants produced by ZC-symptomatic seed tubers were due to chance. However, at Dalhart, the incidence of new infections within $2 \mathrm{~m}$ of plants produced by ZC-symptomatic seed tubers (df $=1, \chi^{2}=4.53, P=0.03$ ) was significantly less than those around the healthy controls. At Olton, incidence of new infections within $2 \mathrm{~m}$ of psyllidborne ZC plants were significantly higher than in plants produced by ZCsymptomatic seed tubers $\left(\mathrm{df}=1, \chi^{2}=\right.$ 16.81, $P<0.0001)$ and healthy controls (df $\left.=1, \chi^{2}=10.77, P=0.001\right)$. At Olton, incidence of new infections around marked individual plants ranged from 0 to 2,0 to 1 , and 0 to 5 for seedborne, healthy, and psyllid-borne, respectively. In Dalhart, the range was from 0 to 3 and 0 to 2 for the seedborne and healthy plants, respectively.

\section{DISCUSSION}

Among ZC researchers, it is a commonly held belief that ZC-affected seed tubers rarely sprout $(10,15)$ and are, therefore, not epidemiologically important. In reality, little information exists concerning sprouting success of diseased potato tubers. In this study, we found that approximately 20 to $40 \%$ of ZC-affected tubers will sprout, depending upon the potato cultivar and severity of ZC within the tubers. This is consistent with a previous report that $20 \%$ of $\mathrm{ZC}$-affected tubers sprouted (15). In contrast, tubers affected by Potato virus $Y$ appear to have normal emergence rates (13), whereas potato tubers affected by ZC generally fail to sprout, have delayed emergence, or produce weak plants that grow for a week or two (10) but then remain in a growth stasis for weeks before dying. In the field, tuberborne ZC hair sprouts die soon after emergence but tend to survive under controlled greenhouse conditions. Nonetheless, the overall symptomatology of seedborne ZC is very similar to that which has been described for seedborne infections of aster yellows in potato (18). Because aster yellows in potato is caused by a phloemlimited phytoplasma, it is not surprising that the symptoms of seedborne $\mathrm{ZC}$, presumptively caused by the phloem-limited ' $\mathrm{Ca}$. L. solanacearum', are very similar.

The most striking result of these studies is that few plants grown in the greenhouse from ZC-affected tubers resembled those growing in commercial potato fields (compare Fig. 1A and D). One possibility is that ' $\mathrm{C} a$. L. solanacearum' titer levels differed within plants grown in the greenhouse versus field-grown plants. Most plants produced by $\mathrm{ZC}$-affected tubers in the greenhouse produced root systems that were considerably shallower and less extensive than healthy controls, in agreement from plants produced by ZC-affected tubers were considerably smaller than those from disease-free plants. Similarly, seedborne Potato leafroll virus also results in smaller progeny tubers than plants grown from healthy seed (3). Some plants produced by ZC-affected seed tubers in the field also produced small progeny tubers; with previous reports (15). Progeny tubers

however, all tubers $(n=50)$ collected from these plants failed to sprout in the greenhouse.

In our greenhouse studies, plants produced by ZC-affected tubers and healthy seed tubers had similar growth patterns. However, stem lengths of plants produced by ZC-affected seed tubers were significantly shorter than healthy controls, particularly over time, and are consistent with the stunting of ZC-affected plants observed in the field. Because seedborne infections of Potato virus $Y$ also cause stunting in Russet Norkotah (4), it can be difficult to correctly assess symptom types in the field. Few plants produced by ZC-affected tubers produced inflorescences, and a small percentage developed into plants that were only slightly different from healthy controls. Under field conditions, these nearly asymptomatic plants would be very difficult to identify.

The color of potato chips made from progeny tubers produced from plants arising from ZC-affected seed tubers was significantly worse than chips obtained from the progeny tubers produced from plants derived from healthy-appearing seed tubers. These results are not surprising. However, there was no difference in chip quality in tubers produced from seed tubers that were ' $C a$. L. solanacearum'positive versus those that were produced from ' $\mathrm{Ca}$. L. solanacearum'-negative seed tubers. Perhaps more interestingly, potato chips made from positive plant foliage were no different from those produced from negative potato plants. Some of this may be due to the fact that aboveground tissues, such as leaf petioles and leaflets, have ostensibly low titers, which result in very low detection efficiencies using PCR assays $(6,20$; this study).

Detection from excised leaf midveins was sporadic. The failure of PCR methods to consistently detect the pathogen in excised foliage may be attributed to low titer or uneven distribution within plants $(1,19)$. 'Ca. L. solanacearum'-free adult B. cockerelli confined with pathogen-positive plants produced by ZC-symptomatic seed tubers failed to acquire detectable levels of the pathogen, despite confinement with these plants for at least 1 week. It is possi-

Table 4. Results of polymerase chain reaction testing for presence of 'Candidatus Liberibacter' in various potato source tissues from plants grown in North Dakota and Texas greenhouses ${ }^{\mathrm{z}}$

\begin{tabular}{|c|c|c|c|}
\hline \multirow[b]{2}{*}{ Source tissue tested } & \multirow[b]{2}{*}{ Source seed tuber } & \multicolumn{2}{|c|}{$\begin{array}{c}\text { Proportion positive for } \\
\text { 'Candidatus Liberibacter solanacearum' }\end{array}$} \\
\hline & & North Dakota & Texas \\
\hline \multirow[t]{2}{*}{ Seed tubers } & Non-ZC-affected & $29 / 36$ & \\
\hline & ZC-affected & $24 / 36$ & $2 / 12$ \\
\hline \multirow[t]{2}{*}{ Leaves/petioles } & Non-ZC-affected & $6 / 98$ & $\ldots$ \\
\hline & ZC-affected & $29 / 64$ & $7 / 50$ \\
\hline Stem & ZC-affected & $\ldots$ & $1 / 13$ \\
\hline \multirow[t]{2}{*}{ Progeny tubers } & Non-ZC-affected & $0 / 95$ & $\ldots$ \\
\hline & ZC-affected & $11 / 43$ & $0 / 14$ \\
\hline
\end{tabular}

${ }^{\mathrm{z}}$ Source tissue tested came from plants arising from either non-Zebra Chip (ZC)- or ZC-affected tubers. 
ble that longer periods of time are required for the pathogen to reproduce inside the vector before titer levels are sufficiently high for detection using cPCR techniques, or insufficient titer was present for successful acquisition. However, ' $\mathrm{Ca}$. L. solanacearum'-free adult $B$. cockerelli confined with field-collected seedborne ZC plants did test positive, and the titer levels in these plants were considerably higher than in plants produced by ZCsymptomatic seed tubers grown from fieldcollected ZC-affected tubers.

Many plant pathogens can be transmitted through seed, not only allowing survival of the pathogen between growing seasons but also providing the means for the pathogen to be distributed efficiently to new areas (12). Based on the results of our field and greenhouse studies, it does not appear as though seedborne infections of $\mathrm{ZC}$ are epidemiologically important, at least in the Texas panhandle. The rationale behind seed- and psyllid-borne comparison is that psyllid-borne ZC plants are generally observed in clusters (unpublished) which probably arise from multiple infec-
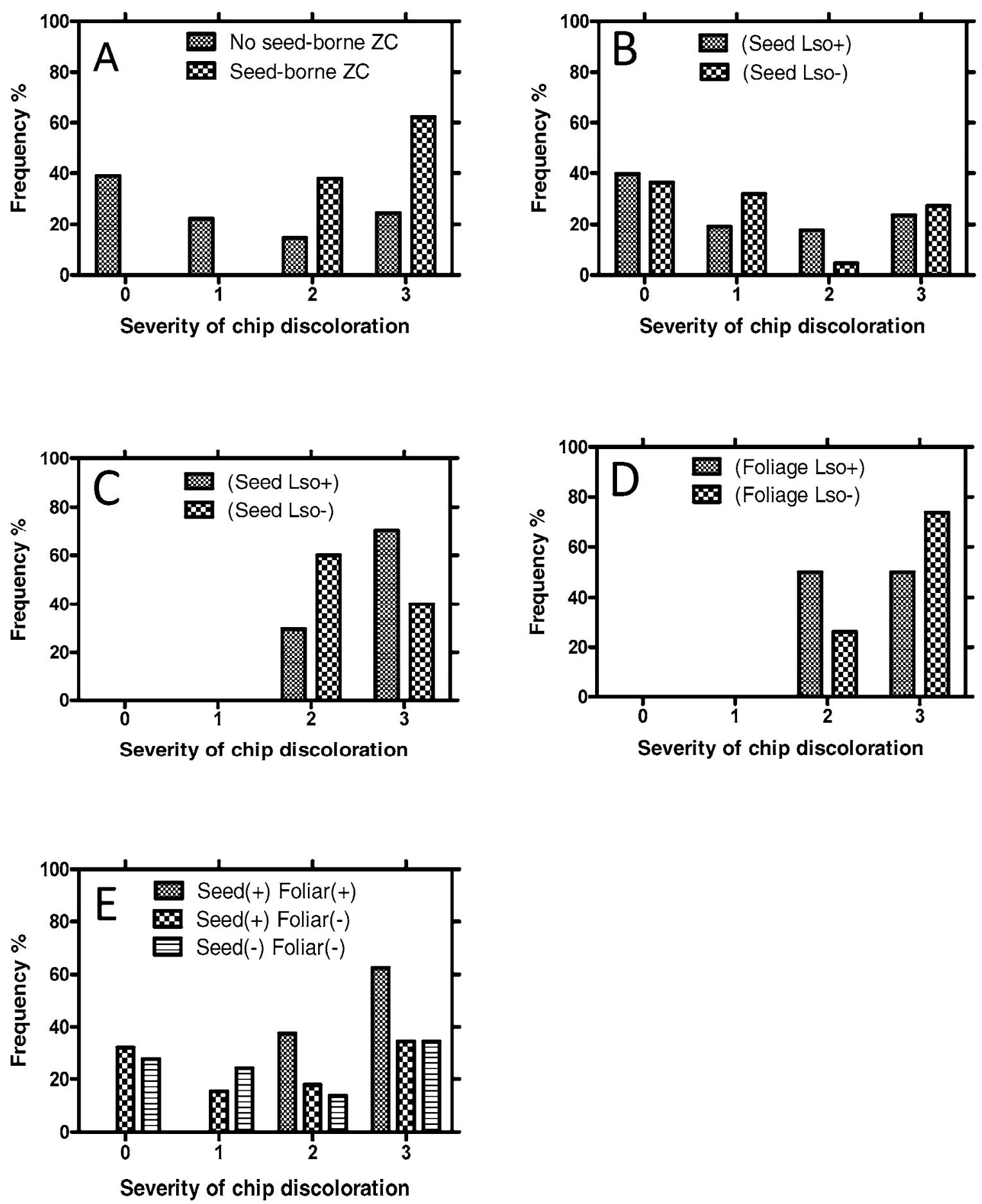

Fig. 2. Impact of tuberborne Zebra Chip (ZC) on fry color. Testing for 'Candidatus Liberibacter solanacearum' (Lso) was performed using conventional polymerase chain reaction primers (5) of $\mathbf{A}$, level of chip discoloration in progeny tubers produced from seed with $(n=90)$ and without $(n=37)$ ZC symptoms; B, level of chip discoloration in progeny tubers produced from seed without ZC symptoms but Lso positive $(n=68)$ or negative $(n=20)$ seed tubers; C, level of chip discoloration in progeny tubers produced from seed with ZC symptoms but Lso positive $(n=27)$ or negative seed $(n=10)$ tubers; $\mathbf{D}$, level of chip discoloration in progeny tubers produced from seed with ZC symptoms but Lso positive $(n=10)$ or negative $(n=23)$ foliage; and $\mathbf{E}$, level of chip discoloration in progeny tubers produced from seed with and without ZC symptoms but Lso positive or negative seed (s) and foliage (f) (s+/f+, $n=8$; $\mathrm{s}+/ \mathrm{f}-, n=84 ; \mathrm{s}-/ \mathrm{f}-, n=29$ ). 
tions caused by movement of a single infective psyllid. Alternatively, noninfective $B$. cockerelli may acquire ' $C a$. L. solanacearum' from initially infected (focal) plants and spread it to neighboring plants. In this study, a significant number of newly infected plants were observed around psyllid-borne ZC plants. However, plants produced by ZC-symptomatic seed tubers did not significantly impact the surrounding healthy plants, which suggests that these plants may not serve as focal points for further spread of the disease in the field. In addition, the density of plants produced by ZC-symptomatic seed tubers was very low in relation to healthy plants. Additional disease surveys in 2009 failed to detect ZC plants anywhere near plants produced by ZC-symptomatic seed tubers that were marked early in the growing season. Concerns that pathogen-free adult $B$. cockerelli will locate these plants, acquire ' $\mathrm{Ca}$. L. solanacearum', and spread ZC to healthy plants may be unwarranted, because these plants are often dead by the time adult $B$. cockerelli arrive, or they are obscured by the canopy of surrounding healthy potato plants. A more immediate concern is the possible annual influx of ' $\mathrm{Ca}$. L. solanacearum'-infective $B$. cockerelli from overwintering regions in south Texas into northern potato fields, including seed production areas in Nebraska, Wyoming, and Colorado. Currently, no seed certification protocols for $\mathrm{ZC}$ are in place to prevent accidental distribution of infected tubers to other regions of the United States or internationally. Movement of infected tubers outside of the range of $B$. cockerelli may not pose a threat to production, because a competent vector would have to be present to locate, feed upon, and successfully acquire and transmit the ZC pathogen.

\section{ACKNOWLEDGMENTS}

This research was supported by the Texas Department of Agriculture Zebra Chip Initiative and ZC SCRI Award no. 2009-51181-20178. We thank J. Gilley, G. Gudmestad, D. Peterson, and R. Sherman for assistance.

\section{LITERATURE CITED}

1. Crosslin, J. M., and Munyaneza, J. E. 2009. Evidence that the zebra chip disease and the putative causal agent can be maintained in potatoes by grafting and in vitro. Am. J. Potato Res. 86:183-187.

2. Gudmestad, N. C. 1991. A historical perspective to pathogen testing in seed potato certification. Am. Potato J. 68:99-102.

3. Hamm, P. B., and Hane, D. C. 1999. Effects of seedborne Potato leafroll virus on Russet Norkotah potato. Plant Dis. 83:1122-1124.

4. Hane, D. C., and Hamm, P. B. 1999. Effects of seedborne Potato virus $Y$ infection in two potato cultivars expressing mild disease symptoms. Plant Dis. 83:43-45.

5. Hansen, A. K., Trumble, J. T., Stouthamer, R., and Paine, T. D. 2008. A new Huanglongbing species 'Candidatus Liberibacter psyllaurous', found to infect tomato and potato, is vectored by the psyllid Bactericera cockerelli (Sulc). Appl. Environ. Microbiol. 74:5862-5865.

6. Li, W, Abad, J. A., Fench-Monar, R. D., Rascoe, J., Wen, A., Gudmestad, N. C., Secor, G. A., Lee, I.-M., and Levy, L. 2009. Multiplex real-time PCR for detection, identification and quantification of 'Candidatus Liberibacter solanacearum' in potato plants with zebra chip. J. Microbiol. Methods 78:59-65.

7. Liefting, L. W., Perez-Egusquiza, Z. C., and Clover, G. R. G. 2008. A new 'Candidatus Liberibacter' species in Solanum tuberosum in New Zealand. Plant Dis. 92:1474.

8. Liefting, L. W., Sutherland, P. W., Ward, L. I., Paice, K. L., Weir, B. S., and Clover, G. R. G. 2009. A new 'Candidatus Liberibacter' species associated with diseases of solanaceous crops. Plant Dis. 93:208-214.

9. Munyaneza, J. E., Crosslin, J. M., and Upton, J. E. 2006. The beet leafhopper (Hemiptera: Cicadellidae) transmits the Columbia Basin potato purple top phytoplasma to potatoes, beets, and weeds. J. Econ. Entomol. 99:268-272.

10. Munyaneza, J. E., Crosslin, J. M., and Upton, J. E. 2007. Association of Bactericera cockerelli (Homoptera: Psyllidae) with "Zebra
Chip", a new potato disease in Southwestern United States and Mexico. J. Econ. Entomol. 100:656-663.

11. Munyaneza, J. E., Goolsby, J. A. Crosslin, J. M., and Upton, J. E. 2007. Further evidence that Zebra Chip potato disease in the lower Rio Grande Valley of Texas is associated with $\mathrm{Bac}$ tericera cockerelli. Subtrop. Plant Sci. 59:3037.

12. Rennie, W. J., and Cockerell, V. 2006. Seedborne diseases. Chapter 13 in: The Epidemiology of Plant Diseases, Second Edition. B. M. Cooke, D. G. Jones, and B. Kaye, eds. Springer, The Netherlands.

13. Rykbost, K. A., Hane, D. C., Hamm, P. B Voss, R., and Kirby, D. 1998. Effects of seedborne Potato virus Y on Russet Norkotah performance. Am. J. Potato Res. 75:91-96.

14. SAS Institute. 2008. SAS/STAT User's Guide. SAS Institute, Cary, NC.

15. Secor, G. A., Rivera, V. V., Abad, J. A., Lee, I. M., Glover, G. R. G., Leifting, L. W., Li, X. and De Boer, S. H. 2009. Association of 'Candidatus Liberibacter solanacearum' with Zebra Chip disease of potato established by graft and psyllid transmission, electron microscopy, and PCR. Plant Dis. 93:574-583.

16. Sengoda, V. G., Munyaneza, J. E., Crosslin, J. M., Buchman, J. L., and Pappu, H. R. Phenotypic and etiological differences between psyllid yellows and zebra chip diseases of potato. Am. J. Potato Res. 87:41-49.

17. Shepard, J. F., and Claflin, L. E. 1975. Critical analyses of the principles of seed potato certification. Annu. Rev. Phytopathol. 13:271-293.

18. Slack, S. A. 2001. Aster yellows diseases Pages 56-57 in: Compendium of Potato Diseases, 2nd ed. W. R. Stevenson, ed. American Phytopathological Press, St. Paul, MN.

19. Tatineni, S., Sagaram, U. S., Gowda, S. Robertson, C. J., Dawson, W. O., Twanami, T. and Wang, N. 2008. In planta distribution of 'Candidatus Liberibacter asiaticus' as revealed by polymerase chain reaction (PCR) and realtime PCR. Phytopathology 98:592-599.

20. Wen, A., Mallik, K., Pasche, J. S., Wang, X., Li, W., Levy, L., Lin, H., Alvarado, V. Y., Scholtof, H., Mirkov, E., Rush, C. M., and Gudmestad, N. C. 2009. Detection, distribution, and genetic variability of 'Candidatus Liberibacter' species associated with Zebra Complex disease of potato in North America. Plant Dis. 93:1102-1115. 